\title{
The Politics of Remembering and Forgetting: Native Title Law and Reconciliation in Australia
}

\author{
Francesca Dominello
}

\begin{abstract}
The post-Mabo era was to be the age of reconciliation and the end of unjust dispossession of Indigenous peoples' lands. However, as the more recent cases in native title show this vision did not become the reality. In this paper, I will examine Mabo in its historical context. In particular I will examine the claim that Mabo was a product of the 'new history' movement in Australia. This movement developed in response to the silence that had shrouded the history of colonial relations between Indigenous and non-Indigenous peoples for most of the 19th and 20th centuries. Through the writing of these histories, new historians have raised awareness of the history of colonization in Australia and the impact it has had on Indigenous peoples in particular. In the paper I will outline the ways in which Mabo is a product of this history. However, if Mabo did not bring to an end to the injustice and inequality facing Indigenous peoples in the context of land law in Australia, it is because of the traces of another history informing that decision and the events that followed it. In this paper I will refer to this history as the 'old history' of Australia. In this history Indigenous peoples are placed in a paradoxical position: they are inferior, but still seen as threat to the colonial enterprise. The paper will explore how this 'history' is repeated in Mabo and continues to inform the High Court's approach to native title law.
\end{abstract}

The post-Mabo era was to be the age of reconciliation and the end of unjust dispossession of Indigenous peoples' lands. However, as the more recent cases in native title have shown, this has not become the reality. In this paper Mabo will be examined in its historical context. As part of the reconciliation movement, Mabo has been identified by some as a product of the 'new history' movement in Australia (Attwood 1996a). This movement developed in response to the silence that had shrouded the history of colonial relations between Indigenous and non-Indigenous peoples for most of the $19^{\text {th }}$ and $20^{\text {th }}$ centuries. Through the writing of these histories, the new historians have raised awareness of the history of colonization in Australia and the impact it has had on Indigenous peoples in particular. The first part of the paper will consider how Mabo may be understood in terms of this history. However, if Mabo did not bring an end to the injustice and inequality facing Indigenous peoples in the context of land law in Australia, this failure may be understood in terms of another version of history, which in this paper will be referred to as the ‘old history’ of Australia. In this history Indigenous peoples are placed in a paradoxical position: they are inferior, but still seen as a threat to the colonial enterprise. The second half of the paper will explore how this 'history' may assist our understanding of the limitations of the Mabo decision and of the more recent High Court cases in native title law, especially with respect to 
their interpretation of the definition of native title in the Native Title Act 1993 (Cth) ('NTA'). By contrast to the reconciliatory sentiment that underlies Mabo and the new history movement that forms part of its background, the third part of the paper will examine the more recent developments in the case law. The paper will conclude by arguing that Mabo may have provided the potential impetus for change in the context of land rights in Australia, but that there are still many obstacles in the way of this change.

\section{Mabo and the New History Movement}

In Mabo for the first time in Australian law a form of Indigenous native title was found, not only to exist, but also to have predated and to have survived the acquisition of British sovereignty. The Court's formulation was grounded in the common law: the common law recognized that native title survived the acquisition of British sovereignty over the Australian territories as a burden on the radical title of the Crown to the land. The content of native title, however, would arise from the traditions and customs of the Indigenous peoples themselves. In order to facilitate the common law recognition of native title, the Court first considered it necessary to reject the terra nullius doctrine as forming no part of Australian law. Whether in fact it was necessary for the Court to 'reject' the 'terra nullius doctrine' remains to be seen, especially since there had been no direct authorities in Australian common law declaring the Australian territories to be 'terra nullius' in those precise terms (Ritter 1996). Even so, if the Court found that the 'terra nullius doctrine' had operated to deny any Indigenous rights to land, it may be because of the characterization of Australia at the time of first settlement as a land belonging to no one. This legal characterization had found support in a line of judicial pronouncements that declared the continent to be in effect 'desert and uncultivated' at the time of British settlement, and provided the framework in which colonization was legitimized (Deane and Gaudron JJ in Mabo, 1992, at 102-4). Thus, even in the absence of direct authorities claiming the Australian territories to be terra nullius, the authorities that supported the ‘discourse of terra nullius’ (Ritter 1996, p. 13) may have led the Court to come to the conclusion that the 'terra nullius doctrine' must be overcome in order for native title to be recognized in Australian law.

Notwithstanding this error, when the authorities treating Australia as 'desert and uncultivated' (in effect 'terra nullius') were translated to the Indigenous inhabitants, the effect was that they were 
deemed to be still living in a state of nature: with no laws, no organized society and no culture. By contrast, the Court's rejection of the 'terra nullius doctrine' was in effect an acknowledgement that the Indigenous inhabitants did belong to organized societies with their own laws and customs. In this way the apparent change in the law can be explained in terms of changed perceptions of Indigenous peoples. Ultimately, this change in perception depended on a change in values. For Brennan J the common law of Australia could not remain 'frozen in an age of racial discrimination’ (Mabo, 1992, at 42), but could be modified to reflect changed contemporary notions of justice and human rights, as manifested in part by international law and the common law as it has developed in other common law countries. Thus, from a legal perspective we can understand the decision in Mabo as finally aligning Australian jurisprudence in relation to native title law with developments in international and Australian domestic law (most notably the rejection of the terra nullius doctrine by the International Court of Justice in Western Sahara (Advisory Opinion) and the enactment in Australia of the Racial Discrimination Act 1975 (Cth) (' $\left.\left.R D A^{\prime}\right)\right)$. We can also understand the High Court's decision in Mabo as bringing Australian law into line with developments in countries such as Canada and the United States. It had already become evident after Blackburn J's judgment in Milirrpum v Nabalco that Australia was lagging behind in this area. Notwithstanding the extent to which jurisdictions elsewhere had extended legal recognition to traditional titles to land, Blackburn $\mathrm{J}$ in Milirrpum rejected the claim for native title in that case on the basis that 'the doctrine does not form, and never has formed, part of the law of any part of Australia' (Milirrpum, 1971, at 141).

However, even at the time of the decision in Milirrpum there was an evident disjuncture between Blackburn J's final determination and his own perception of the Indigenous claimant groups in that case. Indeed Blackburn J accepted the evidence that showed the claimants:

had a subtle and elaborate system highly adapted to the country in which the people led their lives, which provided a stable order of society and was remarkably free from the vagaries of personal whim or influence. If ever a system could be called 'a government of laws, and not of men', it is that shown in the evidence before me (Milirrpum, 1971, at 267).

The evident discrepancy between fact and law in this case is clear:

the Indigenous claimants were found to be socially organized with their own system of laws and government that predated the British arrival, yet there was no legal acknowledgement of that fact. 
It was only in Mabo that this gap was finally bridged through the legal recognition of native title in that case (Dominello 2008a, p. 172).

But while the decision in Mabo reflects a change in the perception of Indigenous peoples and is overtly critical of the colonial practices, policies and laws that contributed to their dispossession in the first place, these developments can be understood more broadly in terms of the work of the new historians in the latter half of the $20^{\text {th }}$ century. For instance in Mabo Deane and Gaudron JJ declared:

If this were any ordinary case, the Court would not be justified in reopening the validity of fundamental propositions which have been endorsed by long-established authority and which have been accepted as a basis of the real property law of the country for more than one hundred and fifty years ... Far from being ordinary, however, the circumstances of the present case make it unique (Mabo, 1992, at 109).

Arguably, if Mabo was no ordinary case then it should be seen as more than just a simple 'correction of a local anomaly' (Nettheim 1993, p. 18), bringing Australia into line with the developments that had occurred elsewhere in the common law world. While it may be true that Mabo was not a 'judicial revolution’, but a mere 'cautious correction to Australian law' (Nettheim 1993, p. 2), there was something much more profound motivating the Court in Mabo 'to change the law' in a way that may only be explained by reference to its broader historical context. Thus, it is one of the contentions of this paper that in order to fully understand the Court's decision in Mabo we must look beyond the pre-existing legal framework that the Court drew upon to support its decision, and acknowledge its broader historical context - and, in particular, the writing of Australian histories from the late 1960s onwards - as contributing to the impetus for change (in law and in society) that culminated in (among other things) the Mabo decision.

There are four significant ways in which the new history writing of the time may be seen as important to the decision in Mabo. First, it is important to acknowledge the role of anthropologists such as WEH Stanner who made the call to break the silence surrounding the history of dispossession in Australia in the late 1960s (Stanner 1969). In a similar vein, the Court can also be seen as actively engaging in the process of breaking the silence surrounding the history of colonial relations in Australia. This was conveyed most forcefully in the joint judgment 
of Deane and Gaudron JJ through their 'acknowledgement of, and retreat from ... past injustices' (Mabo, 1992, at 109) experienced by Indigenous peoples in Australia - the dispossession of their lands. This sentiment directly echoes the sentiment of the new historians - a 'sense of dis-ease' about the silence that had shrouded colonial history in Australia, and a motivation to come to terms with this history in order to overcome it (Attwood 1996a, p. xxix). For new historians 'the continuing colonial crime’ was to keep locked the ‘cupboard of our history’ (Smith 1981, p. 26). The forgetfulness surrounding the history of dispossession was the 'moral issue central to the nation's existence' (Smith 1981, p. 17) and continued to pose 'a central problem for the integrity and authenticity of Australia' (Smith 1981, p. 45). Similarly for Deane and Gaudron JJ there was a recognition in their judgment that '[t]he acts and events by which that dispossession in legal theory was carried into practical effect constitute the darkest aspect of the history of this nation'; and that only by overcoming this history (through rejection of the terra nullius doctrine) could a 'diminished' nation find salvation (Mabo, 1992, at 109). Just as the new historians had recognized that Indigenous peoples had been exposed to serious injustices through colonization, so too had the Court, and in Mabo the Court took the opportunity to do something about it.

Secondly, insofar as the new historians have engaged in the writing of colonial history, the work of Henry Reynolds has proved most influential - not least in the Mabo decision itself. Reynolds himself has acknowledged his own contribution to the decision in various places (Reynolds 1992, pp. 185-202, Reynolds 1993), and his influence is acknowledged by others (Ritter 1996, p. 29; Briscoe 1993, pp. 4-5; Hughes and Pitty 1994, p. 13). Most importantly there are references to his work in the actual judgments (Deane and Gaudron JJ, in Mabo, at 107, 142; Toohey J, in Mabo, at 181). And it has been argued that it was Reynolds' analysis of the terra nullius doctrine as standing in the way of legal recognition of native title that compelled the Court to reject it in the first place (Ritter 1996, p. 29). In other words, if the Court made an error by perceiving the terra nullius doctrine as having operated to deny the recognition of native title in Australia, that error could be traced back to Reynolds' research as he had been the one to launch the term 'into mainstream public debate’ (Ritter 1996, p. 27). As Ritter has described it: 'Reynolds turned the dispossession of Aboriginal People into a "legal" event, in the sense of an event recognised as traceable to the operation of a legal general rule' (Ritter 1996, p. 29). 
More significantly, however, Reynolds’ work had revealed that there had not been a wholesale extinguishment of native title, but that in early colonial times the Colonial Office had recognized the Indigenous occupants' legal interest in the land, and had tried to protect it in 1846 by an Order in Council - which in Reynolds' view 'was a clear and demonstrable recognition of native title: the right to use and occupy land held under traditional title' (Reynolds 1987, p. 139). In this regard Reynolds’ analysis of legal history was at odds with Blackburn J’s conclusions in Milirrpum, and was crucial in raising awareness of the need to correct the law in this area. Indeed, if Reynolds' view is accepted, then the law had always recognized Indigenous peoples' native title rights and interests to their traditional lands: it was the settlers and successive governments, jurists and historians that had got it wrong.

Reynolds' historical work had found traces of earlier attempts to protect native title, although those attempts had failed until Mabo. But if Mabo was an attempt at recovering this lost history, it was also an attempt to recover Aboriginal history. In the writing of new history the new historians not only recovered long forgotten facts of colonial history, but created a space for the writing/speaking of Aboriginal histories. Thus, the third contribution of the new histories to Australian history writing that came to be reflected in Mabo was the valorization of Aboriginal history. This is most evident in the Court's acceptance of the perception of Indigenous peoples as having their own laws and social systems as a basis for 'rejecting' the terra nullius doctrine and extending legal recognition to native title. Moreover, the content of native title was to emanate from the Indigenous claimants themselves. In this regard the oral testimonies of the claimants that related to proof of custom, otherwise termed 'traditional evidence', were accepted by the trial judge, and in turn by the High Court in the final proceedings, as supporting the claimants' contentions concerning the survival and nature of their rights and interests to land (Keon-Cohen 1993, pp. 195-7). Importantly, as in the writing of history, Indigenous peoples were seen as engaged in the process - as active agents in history and in law.

This brings us to the fourth contribution made by the more recent history writing to the Mabo decision. According to more traditional approaches to historical methodology the writing of history entails maintaining strict delineations between past and present (and future): 
so long as scientific methods are adopted, it is possible for the historian and the archaeologist to show the past as it really was and to understand it on its own terms, and thus have independent, historical truth (Attwood 1996a, p. xvi).

This approach assumes 'a radical disjunction between past and present,' treating the past as ‘complete, unchanging and unchangeable,’ and as having an objective existence (Attwood 1996a, p. xx). By contrast, a cluster of 'new' historians have rejected the idea that it is possible to write history in terms of such strict distinctions between past and present. Instead, they take the view that "one always reaches the past "by starting out from the present," and is "always concerned with the meanings of historical reality for us, now"', for it is how the past is interpreted now that will shape the future (Attwood 1996a, p. xvii). According to this approach, the writing of history is performed within the historical context of the present, and its content is informed by the interpretive framework of the historian.

The acceptance of Indigenous peoples' accounts of history, both in historical works and in the law, illuminates how the historical record may be revised and how such revisions may influence change in the law. The acceptance by the High Court of the claimants' evidence in Mabo supported their contentions concerning the survival and nature of their rights and interests to land, and located the source of those rights and interests in their traditional laws and customs. Moreover, by changing the law through acceptance of the pre-existing property rights of Indigenous peoples, and by rejecting what Brennan J described as the 'barbarian' theory of law in response to contemporary values (Mabo, 1992, at 39), Mabo not only represented a shift in the basis for interpreting Australian history by acknowledging the relevance of Aboriginal traditions, but took its place in the broader developing tradition of a history of reconciliation - the end of the age of racial discrimination in Australia: a sentiment also conveyed in the judgment of Deane and Gaudron JJ (Mabo, 1992, at 109).

Admittedly, while the approach in Mabo conforms to the historiographical methodology of the new history movement, it is also true that in any event it is an accepted methodological approach of the common law to modify the law where its presuppositions no longer reflect current social standards - which is in effect the approach that was taken in Mabo. Reflecting on the methodology of the common law, Jeremy Webber has noted: 
It is a much more active process of probing for what is valuable in our past, cherishing what we take to be important, refining it, and basing our further growth and reflection upon it - all elements of a sophisticated grappling with precedent. Respect for precedent involves modesty - a sense that we can and should learn from our own community's past - but it also involves a critical element, in which we actively engage our past, drawing lessons for the future. At times, reflection upon our past (including reflection upon where our community now seems to be moving) leads us to question prior assumptions. We can come to the conclusion that elements that once seemed central to our society are now out of step with, perhaps even antagonistic to, our most cherished commitments (Webber 1995, p. 25).

Importantly, the focus of revision in cases such as Mabo is not merely an interpretive reading of the past, but demonstrates concern for what should be done in the present to chart 'a future course that accords better with what we take to be good in our community’s experience' (Webber 1995, p. 10). As Webber has pointed out, the issue in Mabo 'was not about some action or defect of the remote past':

The defect was very much alive within the law, its application in question today. Often, people presume that Indigenous title is about dispossession long ago. Usually, however, the dispossession is much more recent, often happening in the present. That was certainly the case with Mabo. The Meriam people were still living on their land. They had maintained an unbroken occupation since time immemorial. The court had to decide whether they had a right to that land or whether they were mere sojourners, subject to removal at the government's whim. If dispossession occurred, it would not be in 1788 or in 1879. It would effectively be now, in 1992, by virtue of the judges' action. While the previous cases might be old, it was their present operation, at the end of the $20^{\text {th }}$ century that was in issue. The problem was not one of correcting an ancient injustice, but whether Australian law still took indigenous land, paying no heed to the present inhabitants ... (Webber 1995, pp. 25-6).

Yet, according to the more orthodox view of history and law, dispossession would have already occurred in 1788 (in the case of New South Wales) or 1789 (in the case of Queensland where the proceedings in Mabo arose) with the acquisition of British sovereignty over the Australian territories, notwithstanding the changed circumstances of the present. Indeed, this had been the approach taken by Dawson J (dissenting) in Mabo. Needless to say if this view had prevailed the course of Australian history would have been undeniably different and, from a social justice point of view, all the worse for Indigenous peoples and for the nation as a whole. 
Thus, apart from the developments in the law that the Court relied upon to legitimize its decision in Mabo, the decision can also be understood in terms of the new history writing that had emerged in the decades leading up to the decision, providing versions of Australian history alternative to those that had consciously excluded the impact of colonialism on Indigenous peoples. The Court adopted a similar approach in its recognition of the impact of colonial laws and policies on the Indigenous inhabitants - which, as Brennan J put it, had made them 'intruders in their own homes and mendicants for a place to live’ (Mabo, 1992, at 29). Thus, the Mabo decision demonstrates judicial acceptance of the changing 'truths' about Indigenous peoples and their societies, and acknowledgement of the significant role played by law, and state policies and practices, in undermining their continued survival in Australia. These were truths that had already become apparent through developments in the new history movement; but the significance of Mabo was that it also gave those developments legal effect. The rejection of the 'terra nullius doctrine' was the discursive means by which the Court sought to address the past injustices and discrimination experienced by Indigenous inhabitants, to acknowledge the pre-existing legal systems of the Indigenous inhabitants, and thus to secure a more legitimate foundation for Australian property law by acknowledging that native title had survived the acquisition of British sovereignty.

For some this was an indication that Mabo signalled the potential transformation of the nation by providing a new foundation for the relationship between Indigenous and non-Indigenous peoples in Australia, based on equality of treatment of Indigenous and non-Indigenous property interests. This potential was itself a product of history and reflects acceptance of the 'new Australian history as an interpretation of Australia's colonial past [and Australia’s present and future]' (Attwood 1996a, p. vii). In this way Mabo was not only a turning point in the direction towards reconciliation, but could also be located on the trajectory of the reconciliation movement in law and society. Mabo was itself a reconciliatory event, but was also the product of a history of reconciliation, or what has been termed the 'new history of Australia'. Unfortunately, developments in the context of native title law have demonstrated that much more needs to be done in order to make the end of dispossession and discrimination a reality in the legal context. 


\section{Mabo: Australia's Past, Present and Future}

If the historians in colonial times had come to forget that colonial Australian history involved relations between Indigenous and non-Indigenous peoples, it was because at least by the latter half of the $19^{\text {th }}$ century it had become accepted that Indigenous peoples were not subjects in Australian history, but objects of scientific study. In this 'old history' it was first naturalism and then Social Darwinism that came to dominate the way in which Indigenous peoples were perceived through the eyes of the European colonizers. Naturalism supported the creation of a hierarchical relationship between Indigenous and non-Indigenous peoples: perceived as hunter gatherers Indigenous peoples were thought to be still in a state of nature - assigned to pre-history, and therefore outside history altogether (Davies, 2002, 261-5). When Social Darwinism replaced naturalism it continued to perpetuate the hierarchical relationship between the colonizers and colonized. It was in this period that 'race' clearly became a classifying tool, used not only to distinguish between races, but to place different races at different levels on the scale of civilization, with Indigenous peoples at the bottom. Insofar as these theories came to inform the laws and policies relating to Indigenous peoples they would in turn legitimize inequality of treatment of Indigenous peoples, justify the removal of Indigenous children from their communities and make more land available for non-Indigenous usages. However, the ill effects of colonization on Indigenous peoples were not seen as the consequences of those practices and policies, but as the natural consequences of their inferiority and inability to match the western forces of civilization. Social Darwinism predicted the eventual demise of the Aboriginal race and when that did not become the reality, governments tried to ensure that it would through social engineering. The eventual failure of Social Darwinism would lead to the adoption of assimilationist policies based on anthropological perceptions of Indigenous peoples as capable of being absorbed within the broader mainstream Australian society.

Throughout these periods of colonization the supposed inferiority of Indigenous peoples (and the corresponding superiority of the European colonizers) seemed irreconcilable with the threat that Indigenous peoples appeared to pose to the colonizing processes. A classic example of this paradox can be found in a statement made in 1937 by the second Chief Protector of Aborigines in Western Australia, AO Neville, during discussions of the growing 'Aboriginal problem' that was then facing the states and territories : 
the native population is increasing. What is to be the limit? Are we going to have a population of 1,000,000 blacks in the Commonwealth, or are we going to merge them into our white community and eventually forget that there ever were any Aborigines in Australia? (Commonwealth of Australia 1937, p. 11). ${ }^{1}$

Interestingly, it was the anthropologists, notably Elkin, who in the first half of the $20^{\text {th }}$ century found that Indigenous peoples did in fact have a culture: 'a social, economic, legal, political and religious organization by which they are able to adapt themselves to their geographical and social environment' (Elkin 1934, p. 15). At the time, the anthropologists may have provided the scientific basis for the adoption of the policy of assimilation. Nevertheless, it is clear that it was their perception of Aboriginality that came to inform the High Court decision in Mabo, particularly in the Court's recognition of native title and its corresponding acknowledgement that Indigenous peoples do have systems of laws and societies. Thus, while in its original context anthropological constructions of Aboriginality purported to advance the understanding that Indigenous peoples could be absorbed into white Australian society (in this sense Aboriginality was still seen in negative terms requiring further negation), in Mabo such a construction was applied in positive terms - as a positive recognition of difference.

However, this construction of Aboriginality has not proven to be unproblematic. The problem with the anthropological construction, as with all the other colonial constructions of Aboriginality, is that Aboriginality is perceived as timeless and homogenous, reflecting the natural differences between Indigenous and non-Indigenous peoples. For the early anthropologists like Elkin, once the traits that were proof of Aboriginality were exposed to and tainted by British civilization, it was thought they were lost forever. This understanding has also come to inform developments in the native title context.

Since Mabo there have been numerous High Court decisions in the area of native title. Of these the decisions in Yorta Yorta and Ward are two of the most significant as they set out the Court's understanding of the definition of native title contained in the Native Title Act 1993 (Cth) ('NTA'), which now governs this area of law. According to section 223(1) of the NTA 'native title' is defined as:

\footnotetext{
${ }^{1}$ For an earlier account of this phenomenon see Morris 1992.
} 
the communal, group or individual rights and interests of Aboriginal peoples or Torres Strait Islanders in relation to land or waters, where:

(a) the rights and interests are possessed under the traditional laws acknowledged, and the traditional customs observed, by the Aboriginal peoples or Torres Strait Islanders; and

(b) the Aboriginal peoples or Torres Strait Islanders, by those laws and customs, have a connection with the land or waters; and

(c) the rights and interests are recognised by the common law of Australia.

In Yorta Yorta Gleeson CJ, Gummow and Hayne JJ, in a joint majority judgment in the High Court, dismissed the claimants’ appeal against orders rejecting their native title claim over their ancestral lands that lie across the border of Victoria and New South Wales. The critical issue involved the effect of the 'adaptation and change' (Yorta Yorta, 2002, at 449) that had occurred to the claimant group and their relationship to the claimed lands as a result of colonization. The claimants' argument was that their 'society, whose laws and customs had adapted and changed over time, continued to exist and ... continued to occupy the claim area, or large parts of it, from before European settlement to the date of the claim' (Yorta Yorta, 2002, at 449). The resolution of this issue depended on the joint judgment's interpretation of the word 'traditional' in section 223(1)(a) as it relates to 'the traditional laws acknowledged, and the traditional customs observed, by the Aboriginal peoples or Torres Strait Islanders'.

In support of the claim it was argued that the reference to traditional laws and customs in section 223(1) should be interpreted in the present tense so that they relate to 'traditional laws currently acknowledged and currently observed’ (Yorta Yorta, 2002, at 424):

Section 223(1) does not require that they be the same as those which existed prior to sovereignty. ... A requirement of positive proof of continuous observance and acknowledgment by each generation of ancestors of the claimant group would impose an impossible burden of proof. Such an approach would not allow for adaptation and change. No judgment in Mabov Queensland [No 2] went so far (Yorta Yorta, 2002, at 424).

The High Court disagreed. For the purposes of interpreting 'traditional' as it relates to the traditional laws and customs referred to in the NTA, the joint judgment took as its starting point 
the understanding that 'the origins of the content' of these traditional laws and customs 'are to be found in the normative rules of the Aboriginal and Torres Strait Islander societies that existed before the assertion of sovereignty by the British Crown. It is only those normative rules that are “traditional” laws and customs' (Yorta Yorta, 2002, at 444). Moreover, their Honours found that the NTA requires 'that the normative system under which the rights and interests are possessed (the traditional laws and customs) is a system that has had a continuous existence and vitality since sovereignty' (Yorta Yorta, 2002, at 444). The continued existence of this 'body of norms' (Yorta Yorta, 2002, at 445) depended on an inquiry into whether the society of the claimant group had continued to acknowledge and observe those laws and customs. Thus, in the context of native title the change of sovereignty meant that 'the only native title rights or interests in relation to land or waters which the new sovereign order recognised were those that existed at the time of change in sovereignty. Although those rights survived the change in sovereignty, if new rights or interests were to arise, those new rights and interests must find their roots in the legal order of the new sovereign power' (Yorta Yorta, 2002, at 447). Thus, a native title determination requires us to conduct an inquiry

about the relationship between the laws and customs now acknowledged and observed, and those that were acknowledged and observed before sovereignty, and to do so by considering whether the laws and customs can be said to be the laws and customs of the society whose laws and customs are properly described as traditional laws and customs (Yorta Yorta, 2002, at 447).

However, the joint judgment did concede that 'some change to, or adaptation of, traditional law or custom or some interruption of enjoyment or exercise of native title rights or interests in the period between the Crown asserting sovereignty and the present will not necessarily be fatal to a native title claim' (Yorta Yorta, 2002, at 454; see also 443). How much adaptation or interruption would be acceptable was not entirely clear. ${ }^{2}$ On the issue of adaptation the joint judgment found it was a ‘question' of whether

the law and custom can still be seen to be traditional law and traditional custom. Is the change or adaptation of such a kind that it can no longer be said that the rights or interests asserted are possessed under the traditional laws acknowledged and the traditional customs observed by the relevant peoples ...? (Yorta Yorta, 2002, at 455).

\footnotetext{
${ }^{2}$ But see, eg, Western Australia v Sebastian [2008] FCAFC 65 (2 May 2008).
} 
On the issue of interruption the joint judgment was of the view that a claimant group must establish that 'acknowledgment and observance of those laws and customs must have continued substantially uninterrupted since sovereignty’ (Yorta Yorta, 2002, at 456). This was a necessary requirement as

the rights and interests which are said now to be possessed must nonetheless be rights and interests possessed under the traditional laws acknowledged and the traditional customs observed by the peoples in question. Further, the connection which the peoples concerned have with the land or waters must be shown to be a connection by their traditional laws and customs. ... Were that not so, the laws and customs acknowledged and observed now could not properly be described as the traditional laws and customs of the peoples concerned (Yorta Yorta, 2002, at 456).

The limitation of native title recognition to only those rights and interests that were in existence at the time of the change in sovereignty, and the requirement that the acknowledgement and observance of 'traditional' laws and customs be 'substantially uninterrupted' as proof of continued connection to ancestral lands, reinforce 'old' colonial constructions of Aboriginality the essentialized image of untainted Aboriginality found in anthropologism and the image of the dying race found in Social Darwinism. On this approach the joint judgment in Yorta Yorta could not take into account the impact that colonization had on the members of the claimant group through which they survived; rather the impact was proof of their own demise. The approach could not really accommodate the idea that a society's traditional laws and customs may have evolved over time to become the laws and customs that the group currently acknowledges and observes in relation to their land and waters. Indeed, according to the logic of the joint majority judgment, the claimants' 'society which had once observed traditional laws and customs had ceased to do so and, by ceasing to do so, no longer constituted the society out of which the traditional laws and customs sprang' (Yorta Yorta, 2002, at 458).

However, the emphasis that the joint judgment placed on the date of the acquisition of sovereignty as pre-determining the native title rights and interests that the Court could recognise as 'traditional' under section 223(1) of the NTA may also be understood as an inevitable consequence of some of the unresolved issues in Mabo. However much each of the majority judges in Mabo appeared committed to change the law in a way that would benefit Indigenous peoples they could not undo one fact of Australian history - the acquisition of the Australian 
territories by the British Crown. The legal consequences of this fact are still being felt today. In Mabo the rejection of terra nullius may have paved the way for legal recognition of native title, but this was not matched by the legal recognition of Aboriginal sovereignty. Indeed if the decision in Mabo had in fact involved a need to reject the 'terra nullius doctrine', the Australian territories would have been reclassified as either 'ceded' or 'conquered'. In that case the settlement thesis upon which the classification of the Australian territories is based would have become obsolete and the sovereignty of the peoples in pre-existing occupation would have been acknowledged (although the existing laws could be subject to modification or replacement by the Crown or by Parliament) (Dominello 2008a, p. 176). In fact what did happen in Mabo was that the Court gave legal recognition to a concept of Indigenous property that had its origins in Indigenous customary laws (as evident in the Court's insistence that the content of native title was to emanate from the Indigenous claimants themselves), but continued to take it for granted that within the native title regime Indigenous peoples must continue to look to non-Indigenous institutions for the protection of their native title rights and interests. In Mabo the Court may have given legal recognition to changed perceptions of Indigenous peoples, but the power to make this decision and the framework for deciding native title claims in the future remained squarely within the hands of Australian legal institutions - not Indigenous ones.

Significantly in Mabo Brennan J had found that 'Native title, though recognised by the common law, is not an institution of the common law’ (Mabo, 1992, at 59): an understanding that has been subsequently accepted by the Court in its interpretation of native title under the NTA. However, the corollary of this reasoning is that Australian laws have their origins in the English law. The effect of maintaining such a distinction based on the difference between the origins of Australian laws and native title has been to reclassify racial differences between 'Australians' and Indigenous peoples. Where once distinctions were drawn between the personal traits of the British (and now Australians) and Indigenous peoples, distinctions in the native title context are being drawn on the basis of the differences in the legal origins of their respective laws. However, if the Court has continued to draw these distinctions it has been seen as a necessary step to preserve the acquisition of sovereignty by the British Crown and the Australian legal system that originated from that act. In Mabo the Court itself held that the acquisition cannot be challenged in 
a municipal court (Brennan J in Mabo, 1992, at 31). In Yorta Yorta the joint majority judgment went even further:

the assertion of sovereignty by the British Crown necessarily entailed ... that there could thereafter be no parallel law-making system in the territory over which it asserted sovereignty. To hold otherwise would be to deny the acquisition of sovereignty and ... that is not permissible (Yorta Yorta at 422, 443-4).

Whether the Crown requires such protection remains to be seen. Paradoxically what can be seen in the developments in native title is the perceived difference in origins of Australian law in English law, and native title in Aboriginal customary law, has left native title vulnerable to inferior treatment - the regrettable legacy of the colonial enterprise. This is nowhere more obvious than in Ward.

The native title claim in Ward related to the region known as the East Kimberleys, and covered lands and waters in northern parts of Western Australia (the Miriuwung and Gajerrong claim) and adjacent lands in the Northern Territory (the Ningarmara claim). Because there were competing rights and interests in the claimed land, the issue of whether native title rights and interests could be subject to partial extinguishment, and the general principles applicable to the issue of extinguishment, were crucial. However, in order to determine those issues, it was first necessary to consider what exactly might be subject to extinguishment; that is, the nature of native title as defined by the NTA.

On this issue, the Miriuwung and Gajerrong claimants submitted that the 'occupation approach' that Lee J had applied at first instance, should be adopted and that the 'bundle of rights' approach subsequently taken by the majority of the Full Federal Court should be rejected in this case. According to a 'bundle of rights' approach, native title rights and interests are severable from each other. As thus understood, native title as a 'bundle of rights' is susceptible to partial extinguishment, However, as a title based on occupation, it is not.

In relation to the definition of native title in the NTA the claimants submitted that they

through their predecessor community, occupied exclusively the determination area so that then, as now, they hold a right to exclusive possession. It is a "community title" which is practically 
“equivalent to full ownership”. This conclusion is justified by the concept of "belonging to country", evidenced by the findings of fact, and is supported by the judgment of Brennan $\mathrm{J}$ in Mabo [No 2] (Ward, 2002, at 10-11).

This argument was based on Lee J's judgment at first instance (and on the decision of the Supreme Court of Canada in Delgamuukw v Queen (in right of British Columbia). Justice Lee had treated native title as a communal 'right to land' and had found in relation to the circumstances of this case that "the right ... to "speak for" that land, in particular to "speak for" its use ... justified the finding that there was possession, occupation, use and enjoyment of the traditional homelands of the applicant group' (Ward, 2002, at 11). In this way the claimants posited native title as analogous to a title in fee simple - as proprietary in nature:

Passages in the judgment of Brennan $\mathrm{J}$ in Mabo [No 2] support the view that the interest of a community in exclusive possession of land is proprietary because there are no other proprietors. An identifiable community that was in exclusive possession of land, which is an identifiable community today and which observes customs that are traditionally based, has proprietary title (Ward, 2002, at 12).

The High Court, however, rejected this conceptualisation of native title. In a joint judgment Gleeson CJ, Gaudron, Gummow and Hayne JJ found that the change in sovereignty meant that the right to speak to country - 'the right to be asked for permission to use or have access to the land - was inevitably confined, if not excluded' (Ward, 2002, at 94). The change in sovereignty meant that new rights to control access to land were created. The rights of traditional occupiers to control access to the land may have been affected, but the joint judgment opined that 'because native title is more than the right to be asked for permission to use or have access (important though that right undoubtedly is) there are other rights and interests which must be considered, including rights and interests in the use of the land' (Ward, 2002, at 94). The joint majority judgment also stressed the requirement under section 223(1) of the NTA that the relevant native title rights and interests are only those 'in relation to land or waters': they are the 'rights and interests which are "possessed under the traditional laws acknowledged, and the traditional customs observed”, by the relevant peoples' and who 'by those traditional laws and customs ... “have a connection with” the land or waters in question' (Ward, 2002, at 66). In this way, their Honours limited native title rights and interests to those arising out of the traditional laws and customs that demonstrated the claimant group’s connection to their lands and waters. 
Overall, the joint judgment preferred the ‘bundle of rights’ approach to the occupation approach:

It draws attention first to the fact that there may be more than one right or interest and secondly to the fact that there may be several kinds of rights and interests in relation to land that exist under traditional law and custom. Not all of those rights and interests may be capable of full or accurate expression as rights to control what others may do on or with the land (Ward, 2002, at 95).

In turn the joint judgment rejected the occupation approach:

The fact of occupation, taken by itself, says nothing of what traditional law or custom provided. Standing alone, the fact of occupation is an insufficient basis for concluding that there was what the primary judge referred to as "communal title in respect of the claim area" or a right of occupation of it (Ward, 2002, at 94).

It follows from a 'bundle of rights' approach to the content of native title that native title rights and interests can be subject to partial extinguishment (Ward, 2002, at 89). In fact, the joint judgment found that certain provisions of the NTA 'mandate entire and partial extinguishment' (Ward, 2002, at 63). On this basis, they opined that it was not appropriate to view native title rights and interests as 'a single set of rights relating to land that is analogous to a fee simple' (Ward, 2002, at 91). To do so 'assumes, rather than demonstrates, the nature of the rights and interests that are possessed under traditional law and custom' (Ward, 2002, at 92).

Their Honours, however, did not seem to rule out altogether claims for rights of control over traditional lands arising from the right to speak for country. However, in terms of the 'bundle of rights' approach, such a right could only be one among many of the rights that comprise native title. In fact, a determination under section 225(b) of the NTA is required to state 'the nature and extent of the native title rights and interests in relation to the determination area'; and for anything less than 'a right, as against the whole world, to possession, occupation, use and enjoyment of land or waters', their Honours opined that 'it will seldom be appropriate, or sufficient, to express the nature and extent of the relevant native title rights and interests by using those terms'(Ward, 2002, at 82). ${ }^{3}$ When no such right of exclusive possession exists as native title, 'it will be preferable to express the rights by reference to the activities that may be

${ }^{3}$ But see, eg, Neowarra $v$ Western Australia [2004] FCA 1092 and Sampi v Western Australia (No 2) (2005) 224 ALR 358. 
conducted, as of right, on or in relation to the land or waters' (Ward, 2002, at 83). Thus, in their view now that native title is governed by the NTA, native title could no longer be understood in terms of the common law developments in this area which had been the approach of Lee $\mathrm{J}$ at first instance. Furthermore, the majority's construction in Ward of the connection which Indigenous peoples have with the land - 'country' - as essentially spiritual led them to question whether native title could ever amount to the same entitlements as under the common law (Ward, 2002, at $65,93)$.

Adopting the 'bundle of rights' approach, the joint majority judgment confined its enquiry to those rights and interests of the claimant group that might demonstrate their connection to the claimed area. In this regard, the Court, agreeing with the Full Court majority, rejected the proposition that control of traditional cultural knowledge was a native title right: the 'recognition' of this right would extend beyond denial or control of access to land held under native title (Ward, 2002, at 84). According to the joint judgment, a connection must be made between the rights and interests claimed and the land in question. That connection was missing in relation to these rights. Such rights might involve, for example, the restraint of visual or auditory reproductions of what was to be found there or took place there, and this would fall outside the definition of native title rights and interests in the NTA (Ward, 2002, at 84).

Furthermore, the right to use the resources on the land was limited to a right to use the traditional resources of the land. Thus it was held that no native title right or interest in minerals was established (Ward, 2002, at 185-6). ${ }^{4}$ Moreover, the bundle of rights approach to native title supported the application of the 'inconsistency of rights' test for extinguishment. As applied to various parts of the claimed land, the joint judgment found that the claimants’ rights of controlling access to these areas and making decisions about them had been extinguished, although that did not necessarily extinguish all aspects of native title (Ward, 2002, at 190-8 in relation to the pastoral lease in the Northern Territory; at 138 in respect of the reservation of land for public purposes; at 157-70 in respect of mining leases). Notably, such a dissection of the

\footnotetext{
${ }^{4}$ Even if they had established traditional rights to these resources, the provisions in the Mining Act 1904 (WA) and the Petroleum Act 1936 (WA) had extinguished those rights, at least in relation to the claim over parts of Western Australia).
} 
claimants' rights would not have been possible if the occupation approach had been adopted (Lee $\mathrm{J}$ in Ward, 1998, at 508-10, North J in Ward, 2000, at 516).

It is evident from the joint majority judgment in Ward that a stark contrast between Indigenous law and Australian law effectively meant that common law property precepts could not be used to give substance to Indigenous peoples' conceptions of property (Ward, 2002, at 65). In any event their understanding of the operation of the NTA appears to have precluded any alternative approach to native title based on common law conceptualizations of native title. However, it is also important to acknowledge how the joint judgment established support for its reasoning on the basis of the nature of the relationship between Indigenous societies and their traditional lands. Indeed, the joint majority judgment found that the relationship between Indigenous peoples' and their 'country' was essentially spiritual, and this led them to question whether native title could ever amount to the same entitlement as a common law property title (Ward, 2002, at 93). Again, this was reminiscent of the ahistorical Aborigine of anthropologism that had been accepted by Blackburn J in Milirrpum $v$ Nabalco as 'the fundamental truth about the aboriginals' relationship to the land' (Ward, 2002, at 64).

The reasoning of the joint majority judgment in Ward suggests that the spiritual nature of the connection that Indigenous peoples have to their lands precludes its construction and treatment as a common law property right (Ward, 2002, at 65). One may perhaps wonder why the Court found it necessary to draw such distinctions and not to rely solely on the terms of the NTA. However, by adopting this approach, the majority judgment appeared to accept a tacit distinction between the spiritual (Indigenous conceptions of property) and the economic (non-Indigenous conception of property). ${ }^{5}$ It would appear that such distinctions are reason enough to treat native title as an inferior property entitlement. The Court may have tried to construe this distinction as an inevitable consequence of the operation of the NTA, but it cannot really conceal its own role in continuing to perpetuate such differences. Indeed if non-Indigenous property rights are superior it is because they have been made so in the Australian legal context. The result is that Indigenous peoples are clearly being discriminated against on the basis of race and the perceived differences

\footnotetext{
${ }^{5}$ See also Callinan J in Ward, 2002, at 395-7.
} 
in their conceptions of property that arise from racial differences: there is nothing inevitable about it.

\section{Mabo and the (Post)-Colonial Legacy}

The decisions in Yorta Yorta and Ward show that there still has not been an end to the history of the dispossession and discrimination. Mabo could be seen as a product of new history writing, but it is equally true that the developments in native title law have seen a return to some of the old ways of seeing Indigenous peoples. It is no wonder that when native title claims have failed there are claims made that the terra nullius doctrine continues to pervade Australian law: Indigenous peoples may continue to maintain connections to their ancestral lands, but their presence on the Australian landscape continues to be denied. It may be that in Mabo that both 'new' and 'old' approaches to history coexist, but that ultimately it was the spirit of reconciliation that triumphed in that case. Regrettably, this spirit may have dwindled in the more recent case law.

A significant aspect of the new history movement was to break the silence surrounding the history of colonial relations in Australia. An important aspect of these histories (although by no means their sole focus (Veracini 2003)) was to illuminate the injustices that Indigenous peoples have experienced during this history. The reconciliatory tone set by Brennan J in his appeals to bring Australian laws into conformity with contemporary notions of justice and human rights, and by Deane and Gaudron JJ in their appeals to correct the law and overcome a legacy of grave historical injustices for Indigenous peoples, accord with this historical approach. But they are in stark contrast to the judgments in Yorta Yorta and Ward. Notably at first instance in Yorta Yorta, Olney J was of the view that there was not

any warrant within the Native Title Act 1912 [sic] for the Court to play the role of social engineer, righting the wrongs of past centuries and dispensing justice according to contemporary notions of political correctness rather than according to law. ... [T] This case is not about righting the wrongs of the past, rather it has a very narrow focus directed to determining whether native title rights and interests ... have survived to be recognised and enforced under the contemporary law of Australia (Yorta Yorta, 1998, at [17], [21]).

Furthermore, by contrast to the judgment of Deane and Gaudron JJ in Mabo, with its acknowledgment of the impact of colonization and attempt to address and retreat from past injustices, in Ward such aspirations have been construed as beyond the reach of the courts to 
achieve. In Ward, in even stronger language than that used by Deane and Gaudron JJ in Mabo, McHugh J acknowledged that:

at least on occasions the dominant class in a society will use its power to disregard the rights of a class or classes with less power. On any view, that is what the dominant classes in Australian society did - and in the eyes of many still do - to the Aboriginal people (Ward, 2002, at 231).

Unlike Deane and Gaudron JJ, however, he questioned the role that the Court and the present legal system could play in remedying such injustice - observing that:

redress cannot be achieved by a system that depends on evaluating the competing legal rights of landholders and native-title holders. The deck is stacked against the native-title holders whose fragile rights must give way to the superior rights of the landholders whenever the two classes of rights conflict. And it is a system that is costly and time-consuming. At present the chief beneficiaries of the system are the legal representatives of the parties. It may be that the time has come to think of abandoning the present system (Ward, 2002, at 240-41).

Until the system is changed, however, it is clear that the law of native title in Australia is governed by the statute (McHugh J in Yorta Yorta, 2002, at 467).

Ultimately, the result in Yorta Yorta has seen a return to the silencing of Aboriginal history and the impact that colonial history has had on Indigenous peoples and of the need for remedial relief of this impact. In the High Court the joint majority judgment endorsed the trial judge's conclusion that the claimant group's adherence to traditional laws and customs was irrevocably severed sometime in the late $19^{\text {th }}$ century. This conclusion was largely based on the claimant group's traditional laws and customs as reflected in the written work of Edward Curr, a 19th pastoralist, and not on the oral testimonies of the claimants' own connection to their traditional lands. The joint judgment also specifically endorsed the trial judge's conclusion that an Aboriginal petition in 1881, protesting that 'the government and white settlers' had taken possession of 'all the land within our tribal boundaries', could be used as “"positive evidence emanating from the Aboriginals themselves” to the effect that the descendants of those who had originally occupied the land no longer continued to acknowledge their traditional laws or observe their traditional customs' (Gleeson CJ, Gummow and Hayne JJ in Yorta Yorta, at 450). The petition had originally been tendered by the claimants to demonstrate their history of survival and resistance, by showing that they had continued to struggle for land throughout the period of 
colonization. The distortion of the intention of the petition by the courts effectively turned the notion of Aboriginal agency against the Indigenous claimants themselves: as evidence of continued survival and struggle for land, the petition was (mis)-interpreted as proof of the extinguishment of their rights to their lands.

The entire approach taken by Olney J has been criticized for giving preference to white man's history - not only his version of that history, but the way that he tells that history through the written word, discrediting any oral version of that history (read Indigenous versions) that may contradict the written version (Paul and Gray 2002). Only Black CJ, dissenting in the Full Federal Court, warned of the dangers of accepting colonial accounts of Aboriginal people in colonial times (Yorta Yorta, 2001, at 262-3), and only Gaudron and Kirby JJ, dissenting in the High Court and echoing the approach of Black CJ, could accommodate the effects of colonization on the claimant group (Yorta Yorta, 2002, at 464-5).

Justices Gaudron and Kirby, in their dissenting judgment in Yorta Yorta, disagreed with approaches taken at trial and in the Full Federal Court, insisting that they did not fully appreciate the intention of Parliament to acknowledge a history of dispossession and give protection to native title rights and interests in the NTA:

So much was impliedly recognised in the Preamble to the Act which "sets out considerations taken into account by the Parliament”, including that Aboriginal people and Torres Strait Islanders had been "progressively dispossessed of their lands" (Yorta Yorta, 2002, at 463).

The extent to which the approaches taken by the High Court in Yorta Yorta and Ward have been able to accommodate the effects of colonization on Indigenous claimant groups in other cases has varied according to the circumstances of those cases. Notably, in some recent cases reliance on the conception of the claimants' connection to their ancestral lands as 'spiritual' has, to some extent, helped to address the impact of colonization and for some native title claimant groups has led to positive findings. For instance, in De Rose Wilcox, Sackville and Merkel JJ (confirming the Full Federal Court decision in Ward) found that:

a spiritual connection and the performance of responsibility for land can be maintained even where Aboriginal people have been hunted off the land or it has become impracticable for them to visit. The Full Court said that physical presence is not essential in circumstances where it is no 
longer practicable or access to traditional lands is prevented or restricted by European settlers ( $D e$ Rose, 2003, at [418]).

Their Honours further noted that this approach was not dissented from in the High Court on appeal in Ward. Similar conclusions were made in Daniel in relation to the continuing connection of both claimant groups to their lands: despite the substantial impact of European settlement that had affected the continued occupation on the land, Nicholson $\mathrm{J}$ in that case found that the Yindjibarndi and Ngarluma peoples had maintained a strong sense of connection to their lands (Daniel, 2003, at [421]-[422]).

However, it is to be remembered that the acknowledgement of a spiritual connection to land does not fully accommodate the connection that Indigenous peoples have to their ancestral lands and that it is the land itself that has the spiritual significance for them. At most casting the connection between claimant groups and their lands as 'spiritual' has only mitigated some of the effects of colonization on these groups. It should not be forgotten that the reaffirmation of difference in Ward - stemming from the perceived differences in origin of Australian law and native title - has merely cast Indigenous property precepts as different and inferior to common law property precepts as well as common law conceptualizations of native title: native title as a bundle of rights is not the same as the full ownership of land. Arguably, the adoption of the occupation approach would have been more in line with the claimants' own understanding of their relationship to their traditional lands, since on that approach the land itself would be the focal point of any enquiry into native title (North $\mathrm{J}$ in Ward, 2000, at 515).

Stressing the spiritual nature of the connection that Indigenous peoples have to their traditional lands may further confine native title to 'personal' or 'domestic' rights and interests (as opposed to 'economic' or 'trading' rights) and in this way may limit the success of claims that would help Indigenous peoples to engage in commercial exploitation of any natural resources that may be present on their traditional lands. For instance in Daniel Nicholson $\mathrm{J}$ found that the only native title rights and interests that had survived the acquisition of sovereignty were those:

not exercisable otherwise than in accordance with and subject to traditional laws and customs for personal, domestic and non-commercial purposes (including social, cultural, religious, spiritual and ceremonial purposes) (Daniel v Western Australia [2005] FCA 536 at [4]). 
Notwithstanding that native title rights and interests can include hunting, fishing and gathering rights and interests under section 223(2) of the NTA, the decision in Yorta Yorta, by confining native title rights and interests to those that were in existence at the time of the acquisition of sovereignty, may make it all the more impossible to recognise the existence of rights to trade in resources. This problem had already been foreshadowed in the High Court decision in Yarmirr $v$ Northern Territory (in relation to fishing rights) and in Ward (in relation to rights to minerals). Only in rare circumstances has a Court recognized the commercial rights of a native title claimant group, for example in Lovett on behalf of the Gunditjmara People v State of Victoria where North $\mathrm{J}$ recognized the claimants' traditional rights to trade in eels.

In most cases Australian courts have been unable to accommodate Indigenous forms of economic exchange. Indigenous practices have at best been misconstrued 'as a type of primitive exchange' and at worst re-constituted 'as an absence of economic relations' (Langton, Manzel and Palmer 2006, p. 307). Indeed these cases illuminate another shortcoming of the native title regime. Australian courts have been prepared to say

yes Aboriginal culture was of a type that was capable of supporting a system of laws about ownership and use of the lands but not so far to acknowledge that the system included trade in the resources in or on the lands, or even if Aboriginal people did trade in those resources it was only with each other and therefore not trade in the sense of western trade (McAvoy 2001, p. 4).

In other cases, the effects of colonization have precluded a positive finding of native title completely. For instance, in Risk, the effects of colonization on the claimant group led Mansfield $\mathrm{J}$ to conclude (echoing the High Court majority in Yorta Yorta) that 'the current Larrakia society, with its laws and customs, has not carried forward the traditional laws and customs of the Larrakia people so as to support the conclusion that those traditional laws and customs have had a continued existence and vitality since sovereignty’ (Risk, 2006, at [13]). By contrast, in Bennell v Western Australia Wilcox $\mathrm{J}$ was able to distinguish the facts in that case from those in Yorta Yorta. Finding that the Noongar people held native title over the claim area situated in the Perth region, he noted that 'unlike the Yorta Yorta people ... the south-west community did not suffer a cataclysmic event that totally removed them from their traditional country. Families were pushed around, and broken up ... [h] 
(Bennell v Western Australia, 2006, at 265-6). However, on appeal, the Full Federal Court disagreed with this approach. Justices Finn, Sundberg and Mansfield found the requirement in Yorta Yorta that 'acknowledgment and observance of ... laws and customs must have continued substantially uninterrupted since sovereignty' itself contained an acknowledgement of the effects of European settlement on native title: 'European settlement is what justifies the expression “substantially uninterrupted” rather than "uninterrupted”. It explains why it is that the common law will recognise traditional laws and customs that are not exactly the same as they were at settlement' (Bodney v Bennell, 2008, at 109). But that was as far as the Full Court would go to accommodate the effects of white settlement. The Full Court found that:

if ... there has been a substantial interruption, it is not to be mitigated by reference to white settlement. The continuity enquiry does not involve consideration of why acknowledgment and observance stopped. If this were not the case, a great many Aboriginal societies would be entitled to claim native title rights even though their current laws and customs are in no meaningful way traditional. Yorta Yorta ... would have been decided differently ... (Bodney $v$ Bennell, 2008, at 109).

The question that remains is whether the results in these cases are the inevitable consequences of Mabo: was Mabo only intended to address some but not all of the effects of colonization that had contributed to the dispossession of Indigenous peoples' lands? Clearly the acceptance of the idea of extinguishment of native title, the framing of conditions on which native title could be extinguished and the limits placed on the availability of compensation for past acts of extinguishment, suggest that there were certain events in history that the Court found could not be undone. But it is also to be remembered that each of the judgments in Mabo took a different approach to these issues. As for the requirement for a continued connection to the land as proof of native title, the majority judgments in Mabo differed again. Notably it was only Brennan $\mathrm{J}$ (in the often referred to 'tide of history' passage) who clearly postulated the requirement that to retain native title, a claimant group must still have a connection to their ancestral lands through continued observance and acknowledgement of their 'traditional' laws and customs (Mabo, 1992, at 60). Moreover, according to Brennan J's formulation such a connection (so far as practicable) must have been 'substantially maintained' (Mabo, 1992, at 59). By contrast, Toohey J focused on the nature of the traditional title as 'rooted in physical presence. That the use of land was meaningful [in relation to a society's economic, cultural or religious life] must be proved but it is to be understood from the point of view of the members of the society' (Mabo, 1992, at 188). His 
approach appears to be focused on proof of continuity of the community over time and suggests that it might be sufficient to maintain native title even if the group has lost its traditional customs (Webber 1995, p. 19).

It may be important to point out here that the different views on these issues that were being expressed in 1992 when Mabo was decided may need to be understood within the broader historical context of that decision and more specifically within the interpretive framework of each judge. Moreover, the differences in approach in Mabo meant that there were alternative approaches available to future courts on how to resolve these differences. If the law was to continue to develop in the spirit of reconciliation, those approaches that offered the most protection to native title should have been followed. Given that these approaches were not followed in cases like Yorta Yorta and Ward, one explanation could be that the NTA now precludes their application. However, it is equally true that there was no unanimity in these cases either on the question of how the Act should apply. Both cases specifically related to the nature of the content and proof of native title. In Ward Lee J at trial had continued to postulate the common law understanding that native title was proprietary in nature, notwithstanding the provisions in the NTA. In Yorta Yorta Gaudron and Kirby JJ's interpretation of the definition of native title in the NTA still enabled them to follow Toohey J's formulation in Mabo of the standard of proof required to be met in order to succeed in a claim for native title. In their view 'adaptations, alterations, modifications or extensions of laws previously acknowledged' could fit within the definition of 'traditional laws acknowledged' in s 223(1)(a) of the NTA (Yorta Yorta, 2002, at 264). Moreover, while Gaudron and Kirby JJ found that the continuity of a community was important in determining whether current practices are part of its traditional laws and customs, they also found that:

the question whether a community has ceased to exist is not one that is to be answered solely by reference to external indicia or the observations of those who are not or were not members of that community. The question whether there is or is not continuity is primarily a question of whether, throughout the period in issue, there have been persons who have identified themselves and each other as members of the community in question (Yorta Yorta, 2002, at 264).

Most notably in response to the stringent standard of proof that had been applied by Olney $\mathrm{J}$ at first instance (based on Brennan J's approach in Mabo), Gaudron and Kirby JJ found that '[t]here 
is nothing in ... the definition of "native title" or "native title rights and interests" which requires that "traditional connection with the land ... [be] substantially maintained"' (Yorta Yorta, 2002, at 466). The same argument could be made in response to the joint majority judgment in the High Court: there is nothing in the definition of native title in the NTA which requires that traditional connection with the land be 'substantially uninterrupted'.

Evidently, the NTA can be read in ways that could provide native title with more protection than it has been offered in Yorta Yorta and Ward. Thus, to understand why native title has not been adequately protected it may be necessary to look beyond the current law and at the wider political, social and historical context in which developments in this area of law have taken place. The lingering effects of old colonial approaches to history and Indigenous societies are particularly relevant here. The more recent developments in native title law may be lamented as just another example of the eternal return of colonialism in Australia. Indeed the conservative backlash in response to Mabo, and then subsequently in relation to Wik, most clearly demonstrates how old colonial constructions of Aboriginality are still prevalent in certain influential quarters of Australian society (Attwood 1996b; Marcus 1996). This backlash had its greatest influence on the native title regime, most notably through the amendments to the NTA in 1998 that have further contributed to compounding the inferior status of native title in Australian law (Tehan 2003, p. 555). The unprecedented attacks on the High Court for their decisions in Mabo and Wik may also help to explain the more cautious approach of the High Court in cases such as Yorta Yorta and Ward, confining the recognition of native title to the much more fragile conceptualisation spelled out in those cases. It is also important to acknowledge the extensive resources poured into defending native title claims by public and private bodies alike, and the frequency with which claims are met with the response that native title has ceased to exist (or never existed in the first place). In Ward, the defendants devised arguments that were even more restrictive in scope than those that were finally accepted by the joint majority judgment, in an effort to convince the Court to reject the native title claim completely. Though the joint judgment did not accept these arguments, Callinan J (in dissent) did. Reminiscent of the old version of Australian history Callinan J opined:

The first non-indigenous people who occupied this country brought with them their common and statutory law which had long included a doctrine of adverse possession and settled notions about 
the use and occupation of land. These were closely connected ideas: land was to be used and enjoyed, and those who possessed, used and enjoyed the land should own it ...

Those early non-indigenous settlers also brought with them a knowledge of agriculture and husbandry, and of domestic, commercial and official construction of a kind completely different from that of the indigenous peoples. To the undiscriminating, and perhaps insensitive and unimaginative eyes of the former it must have appeared that much of this large continent was not in fact being used or enjoyed, or certainly not so in a way that was familiar. ...

The different conceptions [about land] held by the new settlers, much the stronger of the peoples, were bound to prevail. This was inevitable when those who were the more powerful had a well settled, long-standing body of property law in written texts, statutes and cases, and those whom they dispossessed depended for the assertions of their rights to occupy and use the land upon traditional oral customs and practices. ...

The problems for the indigenous people were compounded by the difficulty of finding any conceptual common ground between the common and statutory law of real property and Aboriginal law with respect to land. It seems likely that the first settlers would have regarded the two as incompatible, that whatever the Aboriginal peoples possessed by way of title to land was too foreign, fragile and elusive to withstand and survive the common law. Mabo (No2) was a brave judicial attempt to redress the wrongs of dispossession. But ... "recognition" of native title ... has no parallel in the common law. The Court has endeavoured to find a way of recognising, and to a degree protecting, that anomalous interest without unduly disturbing the law of Australian property. The results of this enterprise can hardly be described as satisfactory (Ward, 2002, at 3957).

Furthermore in Yorta Yorta Callinan J accepted an interpretation of the word 'traditional' in the definition of native title in the NTA that confined native title rights and interests to those that were in existence at the time of the acquisition of British sovereignty, but limited the scope of their potential for adaptation and change since that time. Justice Callinan went so far as to say:

The extent to which longstanding law and custom may evolve without ceasing to be traditional may raise difficult questions. The matter went uncontested in Yanner $v$ Eaton, although for myself I might have questioned whether the use of a motor boat powered by mined and processed liquid fuel, and a steel tomahawk, remained in accordance with a traditional law or custom, particularly one of alleged totemic significance (Yorta Yorta, 2002, at 493).

The extensive litigation in cases such as these shows how contentious native title continues to be for those who perceive their interests to be 'under threat' by a native title claim. It also shows how much resistance there can be to engaging in negotiation in native title cases, as an alternative to the adversarial processes of litigation, notwithstanding the provisions for agreement-making 
under the NTA. Indeed in Ward Western Australia decided to hold off engaging in negotiations for an agreement with the Miriuwung Gajerrong traditional owners until after the High Court's decision on appeal (Yu 1999, p. 25-6). In light of the High Court's decision (by contrast to that of Lee $\mathrm{J}$ at first instance) this proved to be an effective strategy, since the government's leverage increased as the claimant group's native title rights and interests were diminished. Even in the case of Yorta Yorta an agreement (though limited in its scope by comparison to what would have been the outcome if the native title claim had succeeded) may have been reached between the Yorta Yorta Nation Aboriginal Corporation ('YYNAC') and the State of Victoria (Seidel and Hetyey 2004), but New South Wales has not engaged with such a process at all. Moreover, the general public response to native title claims also appears to be one of resistance as evidenced by media reports that Wilcox J's decision in Bennell $v$ Western Australia would have meant the closure of public access to beaches. Instances such as these show how divided we are as a nation on the issue of native title and how far we still need to go to adopt the spirit of - let alone achieve - reconciliation in Australia in this area of law.

However, it may be more accurate to interpret the High Court's approach in Yorta Yorta and Ward as exalting certain anthropological perceptions of Aboriginality - the image of Indigenous peoples living in a tribal state untouched by civilization, the timeless Aborigine. It may be no coincidence that this image of Aboriginality, the one that has been most valorized in the Australian popular consciousness, is also the one that has found most protection in native title law. And to a certain degree it is this image of Aboriginality that is favoured among certain historians - even those who subscribe to new historical methods and practices. This has been most patently clear in the tacit support that has been given by some to the limitations that have been placed on native title recognition - most notably the requirement that there be continuous association with the land based on past traditions (Webber 1995, p. 19; Attwood 1996a, p. xxxvii).

Of course, even when Mabo was decided it was never envisaged that it would provide a solution for all Indigenous peoples. In fact it had been predicted that only 5\% of the Indigenous population would benefit from the decision (Aboriginal and Torres Strait Islander Commission 1993, p. 16). Indeed the opposition between 'real’ Aborigines (whose native title has survived), and 
dispossessed Aborigines, whose native title rights have been extinguished and can no longer be revived, had already been foreshadowed in the context of the statutory land rights that pre-dated Mabo. It is no coincidence that the former are statistically more likely to be found in the north of Australia and the latter in urban centres. For instance, in the statutory schemes Aborigines from the Northern Territory are referred to as ‘traditional’ Aborigines (Aboriginal Land Rights (NT) Act 1976 (Cth)), but in more settled areas such as New South Wales, the land rights regime is aimed primarily at dispossessed Aborigines (Aboriginal Land Rights Act 1983 (NSW)). However, as the more recent land reforms in the Northern Territory (Northern Territory National Emergency Response Act 2007 (Cth)) and Queensland (Aboriginal and Torres Strait Islander Land Amendment Act 2008 (Qld)) have shown, such regimes still fail to address the dispossession of those Indigenous peoples in urban centres, nor have they availed to protect Indigenous communal title to land (Watson 2008).

In conclusion, it may appear from the more recent history of native title law that Mabo has turned out to be a lost opportunity to right the wrongs of dispossession and establish equality of treatment for Indigenous conceptions of property. Maybe that opportunity was never there to begin with. As more of the shortcomings of the native title regime become apparent so too does the need for additional remedial action (Pearson 2003; Dominello 2008a; Dominello 2008b). Crucial to these developments will be how Indigenous peoples are perceived and how aspirations for the nation are conceived. Whatever form that action may take, it is to be remembered (as the new historians have indeed reminded us) that any course of action taken now will continue to have ramifications into the future.

\section{References}

\section{Domestic cases}

Bennell v Western Australia (2006) 153 FCR 120.

Bodney v Bennell (2008) 167 FCR 84.

Commonwealth v Yarmirr (2001) 208 CLR 1.

Daniel v Western Australia [2003] FCA 666.

Daniel $v$ Western Australia [2005] FCA 536.

De Rose v South Australia (2003) 133 FCR 325. 
Lovett on behalf of the Gunditjmara People v Victoria [2007] FCA 474.

Mabo v Queensland (No 2) (1992) 175 CLR 1.

Members of the Yorta Yorta Aboriginal Community v Victoria [1998] FCA 1606.

Members of the Yorta Yorta Aboriginal Community v Victoria (2001) 110 FCR 244.

Members of the Yorta Yorta Aboriginal Community (2002) 214 CLR 422.

Milirrpum v Nabalco (1971) FLR 141.

Neowarra v Western Australia [2004] FCA 1092.

Risk $v$ Northern Territory [2006] FCA 404.

Sampi v Western Australia (No 2) (2005) 224 ALR 358.

Ward v Western Australia (1998) 159 ALR 483.

Western Australia v Sebastian [2008] FCAFC 65 (2 May 2008).

Western Australia v Ward (2000) 99 FCR 316.

Western Australia v Ward (2002) 213 CLR 1.

Western Sahara (Advisory Opinion) [1975] ICJR 12.

Wik Peoples v Queensland (1996) 187 CLR 1.

Yanner v Eaton (1999) 201 CLR 351.

\section{Domestic legislation}

Aboriginal and Torres Strait Islander Land Amendment Act 2008 (Qld).

Aboriginal Land Rights Act 1983 (NSW).

Aboriginal Land Rights (Northern Territory) Act 1976 (Cth).

Mining Act 1904 (WA).

Native Title Act 1993 (Cth).

Northern Territory National Emergency Response Act 2007 (Cth).

Petroleum Act 1936 (WA).

Racial Discrimination Act 1975 (Cth).

\section{International legal material}

Delgamuukw v British Columbia (in right of British Columbia) [1997] 3 SCR 1010. 


\section{References}

Aboriginal and Torres Strait Islander Commission. 1993, First Report 1993.

Attwood, B. 1996a, 'Introduction: The past as future: Aborigines, Australia and the (dis)course of history' in Attwood B. (ed), In the Age of Mabo, Allen \& Unwin, Sydney, pp. vii-xxxviii.

Attwood, B. 1996b, 'Mabo, Australia and the end of history' in Attwood B. (ed), In the Age of Mabo, Allen \& Unwin, Sydney, pp. 100-116.

Briscoe, G. 1993, 'Land reform: Mabo and “Native Title”, reality or illusion?', Pacific Research, vol. 6, no. 3, pp. 3-6.

Commonwealth of Australia. 1937, Aboriginal Welfare: Initial Conference of Commonwealth and State Aboriginal Authorities, Canberra, 21-23 April 1937.

Davies, M. 2002, Asking the Law Question: the Dissolution of Legal Theory, Lawbook Co, Sydney.

Dominello, F. 2008a, 'In a world without a sovereign' in Verschuuren, J. \& van Schooten, H. (eds), International Governance and Law, Edward Elgar, Cheltenham, pp. 168-190.

Dominello, F. 2008b, 'Beyond Symbolism: Aboriginal Sovereignty and Native Title', Journal of the Australasian Law Teachers Association, vol. 1, pp. 141-151.

Elkin, A.P. 1934, 'Anthropology and the Future of the Australian Aborigines', Oceania, vol. 5, pp. 1-18.

Hughes, I. and Pitty, R. 1994, ‘Australian Colonialism after Mabo’, Current Affairs Bulletin, vol. 71, no. 1 June/July, pp. 13-22.

Keon-Cohen, B.A. 1993, 'Some Problems of Proof: The Admissibility of Traditional Evidence' in Stephenson, M.A. \& Ratnapala, S. (eds), Mabo: A Judicial Revolution, University of Queensland Press, St Lucia, Qld., pp. 185-205.

Langton, M., Manzel, O. \& Palmer, L. 2006, 'The Spirit of the Thing: The Boundaries of Aboriginal Economic Relations at Common Law', The Australian Journal of Anthropology, vol. 17, pp. 307-321.

Markus, A. 1996, 'Between Mabo and a hard place: race and the contradictions of conservatism' in Attwood, B. (ed), In the Age of Mabo, Allen \& Unwin, Sydney, pp. 88-99.

McAvoy, T. 2001, 'Recent developments in native title seminar', Paper presented at Native Title Representative Body Legal Conference, Townsville, 28-30 August.

Morris, B. 1992, 'Frontier colonialism as a culture of terror' in Attwood, B. \& Arnold, J. (eds), Power, Knowledge and Aborigines, La Trobe University Press, Melbourne, pp. 72-87.

Nettheim, G. 1993, 'Judicial Revolution or Cautious Correction?', University of New South Wales Law Journal, vol. 16, pp. 1-26.

Paul, M.; \& Gray, G. (eds.) 2002, Through a Smoky Mirror: History and Native Title, Aboriginal Studies Press, Canberra.

Pearson, N. 2003, 'The High Court's Abandonment of “The Time-Honoured Methodology of the Common Law" in its Interpretation of Native Title in Mirriuwung Gajerrong and Yorta Yorta', Newcastle Law Review, vol. 7, pp. 1-14.

Reynolds, H. 1987, The Law of the Land, Penguin, Ringwood, Vic. 
Reynolds, H. 1992, The Law of the Land, $2^{\text {nd }}$ ed. Penguin, Ringwood, Vic.

Reynolds, H. 1993, 'What is Native Title’, Wiser, vol. 1, no. 1, pp. 25-30.

Ritter, D. 1996, 'The “Rejection of Terra Nullius” in Mabo: A Critical Analysis', Sydney Law Review, vol. 18, pp. 5-33.

Seidel, P. \& Hetyey, J. 2004, 'Summary of the Yorta Yorta Nation Aboriginal Corporation/State of Victoria Co-operative Management Agreement', Indigenous Law Bulletin, vol. 6, no. 4, pp. 15-17.

Smith, B. 1981, The 1980 Boyer Lectures: The Spectre of Truganini, Australian Broadcasting Commission, Sydney.

Stanner, W.E.H. 1969, The 1968 Boyer Lectures: After the Dreaming, Australian Broadcasting Commission, Sydney.

Tehan, M. 2003, 'A Hope Disillusioned, an Opportunity Lost? Reflections on Common Law Native Title and Ten Years of the Native Title Act', Melbourne University Law Review, vol. 27, pp. 523-571.

Veracini, L. 2003, ‘Of a “contested ground” and an “indelible stain”: a difficult reconciliation between Australia and its Aboriginal history during the 1990s and 2000s', Aboriginal History, vol. 27, pp. 224-239.

Watson, N. 2008, 'The Abuse of Indigenous Land Tenure as a Tool of Social Engineering', Journal of Australasian Law Teachers Association, vol. 1, pp. 163-170.

Webber, J. 1995, 'The Jurisprudence of Regret: The Search for Standards of Justice in Mabo', Sydney Law Review, vol. 17, pp. 5-28.

Yu, P. 1999, 'Possibilities for Regional Agreements in the Kimberley in the wake of the Miriuwung Gajerrong decision’, Indigenous Law Bulletin, vol. 4, no. 21, pp. 24-26. 